\title{
MONGOLIA'S NEW IDENTITY AND SECURITY DILEMMAS
}

\author{
Tsedendamba Batbayar (Mongolia)
}

\section{The Future of Mongolia: Central Asian Identity versus Northeast Asian}

\author{
Mongolia "of which the world knows less than \\ It knows Siberia, or Manchukuo" provides \\ "The key to the destiny of the whole Far East". \\ Owen Lattimore, 1934.
}

D. Byambasuren, former Prime Minister of Mongolia (1990-1992), noted that Mongolia is 'coated at the crossroads of three great civilizations: Christian Russia to the north, Confucian China to the south, and Muslim Central Asia in the west. From the standpoint of Samuel Huntington's Clash of Civilizations, Mongolia is at the vortex of major historical forces. Its location also bestows on Mongolia the potential for building bridges among these great civilizations. After the events of September 11, 2001 (9/11), Mongolia's role as a link of stability between Central and Northeast Asia became more pronounced. Mongolia joined the global coalition against terrorism without any reservation and offered its readiness to contribute to the global fight against terrorism in any possible way. ${ }^{1}$

By the early 1990s Mongolians vigorously debated to which region their country belonged. This was not merely an academic question but had implications for Mongolia's survival as a sovereign state. During the Cold war period, Mongolia solidly belonged to the Soviet-led security system that stretched from its southern Gobi borders all the way to the Berlin Wall. Although Mongolia was physically situated in Asia, its political and economic, trade relations were

${ }^{I}$ Mr. Enkhbayar met US President George Bush at the United Nations on Sunday (Nov 11, 2001) after Mr. Bush made his speech at the UN General Assembly. The meeting is reported to have lasted twice as long as planned. According to a statement from Mongolian government's press office, Mr. Bush expressed deep gratitude for Mongolia's support after the September 11 terrorist attacks. The statement quoted Mr. Bush as appreciating Mongolia's successful venture in establishing democratic institutions and market economy structures and as saying that he is delighted to see Mongolia being governed by young leaders. Mr. Enkhbayar, for his part, said Mongolia had chosen the path of democracy and that there would be no going back on this goal, according to the statement. Mr. Bush is reported to have concluded the discussions by stressing that "Mongolia is our valued partner and we should support each other." Cited from Mongolia This Week, 13 November, 2001. 
tied to the Warsaw Pact countries. The USSR provided important security assurances toward its client states, including military security toward Mongolia.

Now that the USSR has disappeared and Mongolia abandoned by its long-term patron, Mongolia's ruling elite was confronted with the question: who can be our best friends and whom we can trust? To the south of Mongolia, there was the one billion, three hundred million population of China with a dynamic growing market economy but still under strict control of the Communist party. To the north, there was a newly emerged Russia thrown into political, economic, constitutional and federal turmoil with few signs when it will end. To the west, there was Serenity Aziya, (Middle Asia) - a Russian term to distinguish the "Stands" from the rest of Central Asia - newly independent countries with little experience or vision what to do with newly acquired status as sovereign states.

Some Mongols preferred that Mongolia belong to Central Asia geographically, historically, and culturally. Publicist B. Baabar, for example, advocated for the creation of "The Central Asian Security Zone", in which Mongolia can be an active participant along with Turkey. He argued that "throughout their history, the Mongols had been leaders of Turkic nations, and both Mongolia and Turkey have set examples as independent states for other nations in the region to emulate." In his opinion, political Central Asia included five new republics and plus Mongolia, Afghanistan and Azerbaijan. Baabar considered that Germany and Japan can be important allies of Mongolia in the new Central Asia. In case of Germany, Mongolia is attractive because it maintained a substantive network of relations with East Germany and has a comparatively democratic political regime unlike other Central Asian countries. For him, Mongolia is the only ally that Japan has in the Central Asian region and is a convenient route for penetrating the markets of Eastern Siberia and Northern China. ${ }^{2}$

Since the mid-1990s the Central Asian states (except Tajikistan which was still embroiled in civil war) have actively sought to diversify their security relations and form new partnerships outside the context of the CIS or bilateral agreements with Russia. Through reducing their former dependence on Russia it became easier for the Central Asian leaders to assert distinct foreign policies and national security priorities. This has been reflected in the growing engagement in Central Asia of other regional powers - Turkey, Iran and China - as well as the United States and other Western states. The prospects of exploiting the

${ }^{2}$ Baabar B., the Central Asian Security Zone, the Mongolian Journal of International Ajfairs,Ho2, 1995, pp. 18-32. 
rich oil and gas resources in the Caspian region have attracted not only Western but also Asian investors and governments.

Mongolia's dilemma between Central Asia and Northeast Asia had not only the civilization aspect but more importantly it has a clear-cut developmental aspect. This choice implicitly concerns the struggle between the nomadic identities of Mongols vs. its road to modern twenty-first century. It also concerns the vital question of sources for necessary technology and know-how in order not only to overcome the transition period but also to make the country self-sustainable and competitive in coming years and decades. Finally are the calculations from the standpoint of national security. What alliances and alignments will best serve Mongolia's national interests?

In this regard, many argue that Northeast Asia is the preferred choice for alignment. In the opinion of experienced diplomat Kh. Olzvoy, Mongolia should not align itself with Central Asian countries because they comprised another landlocked area and thus could hardly provide much help to Mongolia - a country which was trying to overcome its own landlocked predicament. In addition, all Central Asian countries had just recently become independent and thus lacked the degree of international experience Mongolia required. Third, the political and strategic situation in Central Asia was far from stabilized. Fourth, the Central Asian economies continued to be closely intertwined with that of Russia; finally, the infrastructure in Central Asia was as poorly developed as in Mongolia. ${ }^{3}$

In addition to above-mentioned factors, there was another, more fundamental, difference between new Central Asian states and Mongolia. Mongolia had formal attributes of a sovereign state since ever 1924 and was a member of the UN since 1961. Mongolia had a well-established Ministry of Foreign Affairs and was an active member in several dozen international organizations. However, the Central Asian states had to reinvent every symbol of statehood including flag, anthem, and constitution. They experienced a great shortage of diplomatic cadres and diplomatic skills, which led to a certain naivetŭ, bordering at times on euphoria, in their first foreign policy efforts. If Mongolia acquired its de facto independence because of the Soviet break-up, the Central Asian states acquired their de jury independence, with practically no foundation in real sovereignty.

${ }^{3}$ Olzvoy Kh., A Mongol's view of economic development and cooperation in Northeast Asia, The Mongolian Journal of International Affairs, No 3, 1996, pp. 65-66. 
Why align with Northeast Asia? Mongolian authors argued that it would be much more to Mongolia's advantage to align itself with the Northeast Asian countries and provinces. They justified it by a number of arguments. It is widely expected that the Asia-Pacific region, of which Northeast Asia is an important part, will become extraordinarily important in the next century. In addition, Mongolia will come strategically under the economic "umbrella" of technologically advanced countries like Japan, South Korea, and the United States; it will have improved relations with the Russian Far East and China's Northeast as well as with North Korea; Mongolia's eastern part, where many of the country's mineral resources are located, can be made readily accessible to the rest of Northeast Asia by road and railway, thus giving Mongolia another access to the sea, perhaps through Tumen; and it will give Mongolia the opportunity to serve as a land bridge between Northeast Asia and Europe. ${ }^{4}$

Another persuasive reason to establish close links with Northeast Asia is national security. The choices available to Mongolia in international relations are limited. Landlocked, large in area, and small in population, Mongolia has been dependent on either China or Russia. On a wide range of political, historical and strategic issues, Mongolia has watched both neighbors' policies with apprehension. The USSR break-up triggered a new stage of security concerns for Mongolia, which had viewed the world through the lens of the Sino-Soviet relationship. Now Mongolia looks positively on a new role in the context of Northeast Asia, which can be the bridge to the larger world, and broaden the country's opportunities for security cooperation.

The Concept of Mongolia's Foreign Policy, endorsed by the Parliament in 1994, outlined six foreign policy priorities for Mongolia in the post-Soviet era. The third priority dealt with regional aspects of Mongolian foreign policy. It emerged as a product of compromise between advocates of Central Asian identity versus those who argued for Northeast Asian regional identity. The Concept stated that "the third direction of Mongolia's foreign policy activity shall be strengthening its position in Asia and securing a constructive participation in the political and economic integration process in the region. Within the framework of this objective, greater attention shall be given to Asia and the Pacific region, in particular to Northeast and Central Asia. Mongolia shall take an active part in the process of initiating dialogues and negotiations on the issues of strengthening regional security and creating a collective security mechanism. It

\footnotetext{
${ }^{4}$ Ibid. p. 66.
} 
will strive to become a member of the Asia-Pacific Economic Cooperation Forum (APEC)." 5

Mongolia joined the ASEAN Regional Forum in July 1998 and it constitutes a remarkable achievement of the active policy in the Asia Pacific region. The process presents an institutional channel that will enhance Mongolia's ties with the region, an opportunity to become an integral part of the strategic commu-nity and increase the number of friends in the region.

\section{The Future of Mongolia: Neighbors versus a Third Power}

"Remember the words of Napoleon: each State follows the politics of its geography ". Francois Mitterrand, French President, 1989.

What is geopolitical vision? How much can it be separated from the discussion of national identity? How much does it relate to the "policy belief system" studied by foreign policy analysts? These questions have particular meaning for Mongolia.

Gertjan Dijkink defined geopolitical vision as "any idea concerning the relation between one's own and other places, involving feelings of (insecurity or (dies) advantage (and/or) invoking ideas about a collective mission or foreign policy strategy. " In his opinion, a geopolitical vision requires at least an us and them distinction and emotional attachment to a particular place. ${ }^{6}$

Geopolitical visions may be described as just a subset within the foreign policy belief-system. It is usually described as an "all-encompassing set of lenses through which decision makers perceive their environment". ${ }^{7}$ Geopolitical visions may consist of volatile conceptions of international relations or be conceived as core-beliefs with even deeper roots then those dug out in the usual analysis of foreign policy beliefs, which often relies on well-articulated policy options and easily verbalized visions.

Anthony Smith has listed several features of national identity: an historic territory, common myths and historic memories, a mass culture, a common

\footnotetext{
${ }^{5}$ The Mongolian Journal of International Affairs, No 2, 1995, p. 73.

${ }^{6}$ Gertjan Dijkink, National Identity and Geopolitical Visions, Routlege: London and New York, 1996, p. 11

${ }^{7}$ O.R. Holsti, "The belief system and national images: a case study", Journal of Conflict Resolution, 1962, vol. 6, pp. 244-52, and D. Lowenthal, "Geography, experience and imagination: towards a geographical epistemology", Annals of the Association of American Geographers, 1961, vol. 51, pp. 241-60
} 
economy and common legal rights and duties for all members. ${ }^{8}$ The "historic territory" implies a narrative of conquest, defense, liberation and loss in which again certain "Others " play a role. National identity can hardly be imagined without the feelings of trauma and pride that arise from external relations. In this respect feelings of national identity and geopolitical visions are difficult to separate.

In 1991, right after the democratic reform began in Mongolia; the prominent Mongolian historian Ch. Dalai published an article titled "Don't forget the fact that we have only two big neighbors". He emphasized: "But the two years of 1260 and 1691 are the historical years when Mongolian independence was sold, and it is of no use to try to rehabilitate them. If attempts were made to rehabilitate them, then it would be against the heroic Mongolian rightful state. "The two dates he mentioned, are closely connected with trauma and pride in Mongolian external history. In 1260, Khubilai Khan moved the capital of the Mongol empire from Karakorum to Shandu in China, and thus, according to Professor Dalai, transferring the heart of the Mongol empire from Mongolia proper to China. In 1691, the Khalkha Mongolia submitted to the Manchus, thus opening more than 200 years of Qing dynasty domination of Mongolia.

His remarks reflect the deep-rooted feelings of the Mongolian elite that Mongolia is "sandwiched" between two giants, namely, Russia and China. The constant struggle to come out from this "trapped", "hopeless" vicious circle dominates the whole twentieth century history of Mongolia. A Western historian calls the situation as "between the hammer and anvil?" 10

A Mongolian historian called his own country as "A puppet republic " whose fate was manipulated by its neighbors for most of the twentieth century. ${ }^{11}$ This strand of political realism, a notion of "geographical determinism", remains very strong in foreign and security policy thinking in contemporary Mongolia. A political debate in the 1990s centered on what kind of policy to adopt with respect to the two neighbors: whether to:

1. Maintain an alliance or special relations with Russia, bearing in mind Mongolia's twentieth century history, national experience and still heavy economic dependence on Russia; this option was rejected in light of recent experience, when during the Sino-Soviet confrontation between 1960 and mid 1980s

\footnotetext{
8 A.D. Smith, National Identity, London: Penguin Books, 1991, p. 14.

9 Unen, June 25, 1991

${ }^{10}$ Ewing. Between The Hammer and Anvil?, Bloomington, Indiana University Press. 1980.

${ }^{11}$ Baabar B., (1999) Book Three. A Puppet Republic, History of Mongolia, Cambridge* the White Horse Press,
} 
Soviet troops were stationed in Mongolia, which virtually became a hostage of Sino-Soviet relations. Most of the outside world did not exist for Mongolia because its foreign policy was entirely under Moscow's command. Bearing in mind experiences from the Sino-Soviet dispute, Mongolia also declared that in case of future disputes between Russia and China, it would pursue a policy of non-involvement and neutrality, unless the disputes affect its vital national interests. In the latter case, the concept declared, Mongolia would follow its vital interests.

2. to declare strict neutrality (like Switzerland, for example) This second option was also rejected on the grounds that strict neutrality of a small, economically weak, land-locked state, sandwiched between two major competing powers would not hold because of its economic and political vulnerability to outside pressure. Strict neutrality would require a degree of political and economic weight that Mongolia does not possess.

3. To find some other suitable "prescription" that would take into account Mongolia's geopolitical reality and the interests of its neighbors without compromising Mongolia's own sovereignty. The concepts of a "multi-pillar foreign policy" and a "balanced relationship" with regard to its powerful neighbors emerged from this debate and was documented in the "Concept of national security" in 1994. Maintaining a balanced relationship was not seen as keeping equidistant between them or taking identical positions on all issues. This policy meant strengthening trust and developing all-round good-neighborly relations and mutually beneficial cooperation with both of them.

Current Foreign Minister L. Erdenechuluun stresses the insecurity and disadvantage which Mongolia experiences. He wrote: "In case of Mongolia, as with many other nations, its geographical location has a major bearing on the entire spectrum of its foreign and domestic policies. A feature, however, that few nations, if any, possess, is the fact that Mongolia is sandwiched between two great powers, namely, the Russian Federation and the People's Republic of China. Both are nuclear powers and sit on the United Nation's Security Council as its permanent members. Mongolia does not have direct access to the sea, and this only adds to the disadvantage." 12

Why do Mongols want to have a third partner or a third neighbor? Answers may vary. But the main logic is again political realism or Mongolian "realpolitik". Mongolian authors generally agree that because of the lack of

${ }^{12}$ Erdenechuluun L., (1999) Mongolia's strategic options, Northeast Asia towards 2000: Interdependence and Conflict? Kyongsoo Lho/ Kay Moller edited, Baden-Baden. Pp. 93. 
necessary political and economic weight to implement its declared national security policy, Mongolia needs a strong third power as a counterweight to balance its relations with the immediate neighbors.

In this respect, the view of L. Erdenechuluun is typical of Mongolian thinking. He wrote "Trying to reduce the possibility of an unpredictable turn of events that might affect their existence and security, small and weak countries have often turned to third parties so as to balance their relations with immediate neighbors. Whereas this has been true for Mongolia in principle, a single regional player able to outweigh Russia and China can simply not be conceived of in the foreseeable future. One might therefore not think of this neighbor in terms of a single country, but rather as a group of countries, especially those which have consistently supported democratic change in Mongolia." ${ }^{13}$

The current leadership of Mongolia is keen to invite investment and more advanced technology from the Western countries and sees their involvement as a form of protection for Mongolia's future. PM N. Enkhbayar in his interview to the Far Eastern Economic Review said that "ties with such countries will make Mongolians feel more secure economically, technologically and even psychologically." 14

The Far Eastern Economic Review also wrote that "Worries about Mongolia's geographical isolation and fears about the intentions of its neighbors, particularly China which is viewed with deep suspicion by many Mongolians, have prompted Ulan Bator to follow a "multi-pillar" foreign policy aimed at cementing ties with other countries. One of these pillars is military. Mongolia's small army has relations with a wide range of countries including China, Russia, the U.S., South Korea, Japan, India and Germany. Last year it took part in a peacekeeping training exercise in Kazakhstan that brought together troops from Central Asia, Russia and the North Atlantic Treaty Organization. Mongolia also has a dialogue with NATO and, officials say, is ready if asked to send a small contingent of troops to the United Nations operation in East Timor. These military contacts, particularly with the U.S., annoy Beijing, officials say, but are all part of a complex balancing act aimed at keeping Mongolia's two powerful neighbors at a distance." 15

PM Enkhbayar during his recent visit to the U.S. (November 2001) delivered a speech titled 'Mongolia's contribution to the global fight against terrorism" at the United States Institute of Peace. Among other things he elaborated

\footnotetext{
${ }^{13}$ Erdeneculuun B. (1999), pp. 95.

${ }^{14}$ Far Eastern Economic Review May 31, 2001.

${ }^{15}$ Ibid.
} 
on his geopolitical vision about future of Mongolia. He broadened the concept of the third neighbor including not only Western countries but East Asian countries and even India. He talked about India as the third neighbor in cultural sense, about Korea and Japan as the third neighbors in economic terms and about the U.S. and the European Union as the third neighbors in strategic terms. Enkhbayar's background as a devout Buddhist is evident in his admiration of India as the cultural and civilization friend for Mongolia. Mongolia's search for its third neighbor continues.

As Sherman Garnett wrote, "What many U.S. analysts regard as Asia's "backside" or even "backwater" is already becoming increasingly linked to lands on Asia's rim. Thus, areas once remote from U.S. strategic planning will have an increasingly direct influence on areas of vital interest in East Asia and the Persian Gulf' ${ }^{16}$ After 9/11 the new U.S. presence in Central Asia has reinforced the emerging post-Cold War reconnection of Central Asia with East Asia. Therefore, a democratic and prosperous Mongolia, located strategically between two regions, can play an important role as the link of stability between dynamic East Asia and volatile Central Asia.

${ }^{16}$ Rapprochement or Rivalry? Russia-China Relations in a changing Asia, Sherman W. Garnett edited, Washington: Carnegie Endowment, 2000, pp. 34. 